\title{
Determinan Kualitas Pelayanan, Harga dan Produk Terhadap Kepuasan Pelanggan Telkomsel Flash Di Bondowoso
}

\author{
Wardatul Insyroh $^{1^{*}}$, Trias Setyowati $^{2}$
}

${ }_{1,2}$ Fakultas Ekonomi Universitas Muhammadiyah Jember

\section{A R T I C L E I N F O}

Article history:

Received 19 May 2018

Received in revised form

15 June 2018

Accepted 19 July 2018

Available online 29 August 2018

Kata Kunci:

kualitas pelayanan, produk,

harga, kepuasan pelanggan

Keywords:

service quality, product,

price, customer satisfaction

\section{A B S T R A K}

Penelitian ini bertujuan untuk mengetahui pengaruh kualitas pelayanan, produk dan harga secara parsial terhadap kepuasan konsumen Telkomsel Flash di Kabupaten Bondowoso. Populasi pada penelitian ini adalah seluruh pelanggan Telkomsel Flash di Bondowoso. Teknik penentuan ukuran sampel menggunakan rumus Slovin, dan diperoleh jumlah sampel sebanyak 100 responden. Pengujian hipotesis dilakukan dengan menggunakan analisis regresi linear berganda. Hasil yang didapat pada penelitian ini menunjukkan bahwa kualitas pelayanan, produk dan harga berpengaruh positif dan signifikan terhadap kepuasan pelanggan Telkomsel Flash di Bondowoso. Hasil analisis koefisien determinasi menunjukan bahwa $71,5 \%$ kepuasan pelanggan dipengaruhi oleh kualitas pelayanan, produk dan harga. Sedangkan sisanya sebesar $28,5 \%$ dipengaruhi oleh variabel lain diluar model.

\section{A B S T R A C T}

This study aims to determine the effect of service quality, product, and price of partially to consumer satisfaction Telkomsel Flash in Bondowoso City. The population of this study were all consumers of Telkomsel Flash in Bondowoso. Determination technique of sample size using Slovin formulas, and obtainable sample size of 100 respondent. Hypothesis test in this research uses double degree linear regression. The result of this research show that service quality, product and price positive significantly influence on customer satisfaction Telkomsel Flash in Bondowoso. The results of coefficient determination shows that $71,5 \%$ of consumer satisfaction influenced by service quality, product and price. While the remaining $28,5 \%$ is influenced by other variables outside the model.

\footnotetext{
* Corresponding author.

E-mail addresses: penulis1@undiksha.ac.id (Wardatul Insyroh)
} 


\section{Pendahuluan}

Era yang semakin modern membawa masyarakat memasuki dunia yang lebih cepat dan instan. Aktivitas sehari-hari yang dilakukan manusia akan lebih efektif dengan menggunakan teknologi yang canggih. Salah satu teknologi yang dimanfaatkan masyarakat dalam kehidupan sehari-hari adalah International Network atau internet. Dengan internet masyarakat dapat dengan mudah mencari informasi, berkomunikasi, berbisnis, dan melakukan banyak hal lainnya. Untuk memenuhi kebutuhan tersebut maka masyarakat menginginkan layanan akses internet yang cepat dan tanpa hambatan (Suriyani, 2017).

Ketergantungan masyarakat terhadap internet, membuat kompetisi bisnis telekomunikasi operator seluler semakin intens. Hal tersebut memberi dampak pada persaingan kualitas produk dan harga, yang menuntut para pemasar dapat menyediakan produk yang berkualitas dengan harga terjangkau. Selain itu, perusahaan dituntut untuk mengembangkan suatu produk yang bermanfaat dan inovatif sesuai dengan harapan dan kebutuhan pasar, dengan harapan pelanggan akan merasa puas setelah menggunakan produk dan melakukan pembelian produk yang sama secara berulang di masa datang (Sari dan Utama, 2016).

Salah satu syarat yang harus dipenuhi suatu perusahaan agar dapat mencapai sukses dalam persaingan adalah menciptakan dan mempertahankan pelanggan (Bacmid, et al, 2016). Untuk menciptakan dan mempertahankan pelanggan tersebut, perusahaan perlu menerapkan strategi pemasaran yang tepat. Strategi pemasaran menurut Assauri (2008) adalah serangkaian tujuan dan sasaran, kebijakan dan aturan yang memberi arah kepada usaha-usaha pemasaran perusahaan dari waktu ke waktu, pada masing-masing tingkatan dan acuan serta alokasinya, terutama sebagai tanggapan dari keadaan persaingan perusahaan yang selalu berubah. Definisi dari pemasaran sendiri ialah proses analisis, perencanaan, pelaksanaan dan pengendalian atas barang atau jasa untuk menciptakan kepuasan pelanggan.

Kepuasan pelanggan adalah tujuan utama perusahaan. Menurut Kotler dan Keller (2009) kepuasan adalah perasaan senang atau kecewa seseorang yang timbul setelah membandingkan kinerja yang dirasakan atas suatu produk dengan ekspektasi yang diharapkan. Apabila kinerja tidak sesuai dengan harapan maka pelanggan tidak merasa puas, sebaliknya apabila kinerja melebihi harapan maka pelanggan akan sangat puas. Umumnya Konteks kepuasan pelanggan adalah harapan dari pelanggan yang merupakan keyakinan atau perkiraan pelanggan tersebut tentang apa yang akan diterimanya yagn diungkapkan baik lisan maupun non lisan (Maulana, 2016).

Untuk menciptakan kepuasan pelanggan diperlukan beberapa faktor, salah satunya adalah kualitas pelayanan. Kualitas pelayanan menurut Lovelock (dalam Tjiptono 2006) adalah tingkat mutu yang diharapkan, dan pengendalian keragaman dalam mencapai mutu tersebut untuk memenuhi kebutuhan pelanggan. Kualitas pelayanan yang melebihi harapan pelanggan akan membuat pelanggan merasa puas. Berdasarkan pendapat Parasuraman (dalam Nugroho, 2014) terdapat lima dimensi pokok kualitas pelayanan yaitu keandalan (relliability), daya tanggap (responsiveness), jaminan (assurance), kemudahan akses (emphaty), penampilan fisik (tangible).

Selain kualitas layanan yang baik, harga juga merupakan faktor penting dalam sebuah usaha. Kotler dan Amstrong (2007) menyatakan bahwa definisi harga adalah sejumlah uang yang harus dibayar oleh pelanggan untuk memperoleh produk. Harga merupakan salah satu faktor yang harus dikendalikan secara serasi dan selaras dengan tujuan yang ingin dicapai perusahaan (Hutapea, 2016). Penetapan harga didasarkan atas pertimbangan besarnya biaya produksi dan berbagai faktor lainnya agar perusahaan dapat memperoleh laba. Selain itu, penetapan harga harus disesuaikan dengan keinginan, kebutuhan dan kemampuan pelanggan agar perusahaan dapat menarik minat dan mampu mempertahankan kesetiaan pelanggan.

Mengingat banyaknya pilihan operator seluler di Indonesia, membuat pelanggan selektif dalam pemilihan dan penggunaan produk operator seluler. Disamping faktor harga, kualitas produk juga sangat diperhatikan konsumen. Produk adalah segala sesuatu yang ditawarkan perusahaan ke suatu pasar untuk diperhatikan, dimiliki, dan dikonsumsi sehingga dapat memuaskan keinginan dan kebutuhan pelanggan (Saladin, dalam Bachmid, 2016). Semua pelanggan menginginkan produk yang tidak hanya murah, namun juga berkualitas. Dengan menciptakan produk yang berkualitas, perusahaan akan memperoleh kepercayaan serta menciptakan kepuasan pelanggan.

Berdasarkan penjelasan di atas penelitian mencoba mengetahui pengaruh kualitas pelayanan, harga, dan produk terhadap kepuasan pelanggan. Alasan pemilihan variabel independen tersebut mengacu pada hasil penelitian terdahulu yang dilakukan oleh Sari dan Utama (2016) yang menemukan hasil bahwa kualitas layanan, kualitas produk, dan harga berpengaruh positif dan signifikan terhadap kepuasan konsumen pengguna XL di Yogyakarta. Dalam penelitian lain Suwarni dan Mayasari (2011) menemukan hasil bahwa kualitas produk dan harga berpengaruh terhadap kepuasan konsumen Indosat IM3 di 
Universitas Negeri Malang. Sedangkan Hutapea (2016) menemukan hasil bahwa kualitas produk dan harga berpengaruh terhadap kepuasan konsumen pengguna Telkomsel di Universitas Asahan Medan, begitupula dengan penelitian Utami dan Trenggana (2016), Santoso (2016) yang menemukan hasil bahwa kualitas produk dan harga berpengaruh terhadap kepuasan konsumen pengguna Telkomsel di Universitas Telkom Bandung. Oleh karena itu, penelitian ini bertujuan untuk memperkuat hasil yang telah diperoleh penelitian terdahulu degan menggunakan perusahaan dan wilayah yang berbeda sehingga bisa digeneralisasikan pada perusahaan operator seluler lainnya.

Perkembangan teknologi informasi di Indonesia saat ini semakin pesat. Seiring dengan perkembangan tersebut, beragam perusahaan operator seluler juga bermunculan dan saling berlomba memberikan pelayanan terbaiknya untuk pelanggan. Persaingan antar operator seluler dalam menarik dan mempertahankan pelanggan merupakan suatu keuntngan bagi masyarakat. Pelanggan bisa menikmati pesta tarif karena para operator menurunkan tarif sebagai langkah memberi kepuasan kepada pelanggan.

Salah satu perusahaan telekomunikasi yang turut bersaing di pasar adalah Telkomsel. Telkomsel merupakan operator seluler terbesar di Indonesia dengan pencapaian 178 juta pelanggan hingga November 2017 yang tersebar diseluruh wilayah Indonesia. Telkomsel juga terus mengembangkan bisnis digital, diantaranya Digital Advertising, Digital Lifestyle, Mobile Financial Services, dan Internet of Things. Telkomsel memiliki tujuan untuk menginspirasi masyarakat dengan memanfaatkan teknologi terdepan, produk dan layanan yang kompetitif, serta solusi inovatif (telkomsel.com).

Saat ini telkomsel memiliki 4 produk operator seluler yaitu kartu Halo, Simpati, As, dan Loop. Untuk menarik minat konsumen dan mempertahankan pelanggan, Telkomsel khususnya kartu Simpati memberikan berbagai pilihan paket murah untuk telepon, sms, dan internet. Selain itu, Telkomsel juga mempunyai layanan Telkomsel Poin yang merupakan program loyalitas pelanggan yang ditujukan untuk seluruh pelanggan Telkomsel. Program Telkomsel Poin bertujuan untuk memberikan penghargaan kepada para pelanggan Telkomsel yang telah setia menggunakan produk dan layanan Telkomsel.

Perkembangan pelanggan pengguna Telkomsel di Indonesia dapat dikatakan meningkat. Hal tersebut dapat dilihat dari data jumlah pengguna Telkomsel 5 tahun terakhir yaitu pada Tahun 2013 hingga 2017 yang disajikan dalam Tabel 1.1 dibawah ini:

Tabel 1. Jumlah Pengguna Telkomsel Tahun 2013-2017 (Dalam Juta Orang)

\begin{tabular}{ll}
\hline Tahun & Jumlah Pengguna Telkomsel \\
\hline 2013 & 131,5 \\
2014 & 140,6 \\
2015 & 152,6 \\
2016 & 173,9 \\
2017 & 178 \\
\hline
\end{tabular}

Sumber: Laporan PT. Telekomunikasi Seluler (telkomsel.com)

Dari tabel 1.1 di atas diketahui pada tahun 2013 pengguna operator seluler Telkomsel di seluruh wilayah Indonesia adalah sebesar 131,5 juta orang, tahun 2014 sebesar 140,6 juta orang, dan tahun 2015 sebesar 152,6 juta orang. Jumlah ini terus meningkat hingga tahun 2017, dimana pada tahun 2016 pengguna Telkomsel bertambah sebanyak 21,3 juta sehingga menjadi 173,9 juta orang, dan tahun 2017 menjadi 178 juta orang. Perkembangan ini merupakan indikasi bahwa semakin banyak penduduk Indonesia yang mempercayai Telkomsel sebagai produk yeng tepat dan mereka merasa puas terhadap kinerja Telkomsel.

Salah satu produk atau layanan yang ditawarkan Telkomsel adalah Telkomsel Flash. Telkomsel Flash merupakan layanan internet tanpa kabel (wireless) yang disediakan Telkomsel untuk seluruh pelanggannya (simPATI, AS, Loop, dan Halo). Paket Flash adalah penawaran paket internet berbasis Volume yang dapat diakses melalui jaringan Telkomsel dengan berbagai pilihan kuota yang berbeda untuk masing-masing produk (Telkomsel.com). Layanan ini didukung dengan teknologi 4G/HSDPA/3G/EDGE/GPRS yang dapat menghasilkan kecepatan download dan browsing sampai dengan 14,4 Mbps. Mobile broadband Telkomsel Flash memiliki jangkauan terluas di Indonesia, sehingga koneksi internet dapat stabil. Telkomsel Flash juga cepat dan mudah digunakan, karena dapat dibeli secara berlangganan ataupun sekali beli dengan menggunakan aplikasi My Telkomsel atau melalui *363\#.

Penelitian ini menggunakan PT. Graha Central Indo (GCI) sebagai objek penelitian. PT. Graha Central Indo merupakan perusahaan yang menjadi salah satu dealer nasional yang bergabung menjadi distributor Telkomsel yang terus berkembang, serta menjadi mitra AD Telkomsel untuk cluster jawa timur, khususnya Jember dan Bondowoso. Saat ini, PT. Graha Central Indo menjadi dealer dengan fokus area dan 
manajemen yang rapi dan teratur, dan terus mengembangkan produk Telkomsel menjadi operator seluler terbaik (ptgci.co.id). Tabel 1.2 berikut merupakan data jumlah outlet di Bondowoso yang menjadi pelanggan atau berada dalam naungan PT. Graha Central Indo Bondowoso dari Tahun 2013-2017:

Tabel 2. Jumlah Outlet di bawah PT. Graha Central Indo Tahun 2013-2017

\begin{tabular}{lc}
\hline Tahun & Jumlah Outlet di Bondowoso \\
\hline 2013 & 422 \\
2014 & 476 \\
2015 & 509 \\
2016 & 568 \\
2017 & 628 \\
\hline
\end{tabular}

Sumber: Data PT.GCI Bondowoso

Dari data tabel 1.2 dapat diketahui bahwa setiap tahunnya jumlah outlet yang menjadi pelanggan PT. Graha Central Indo Bondowoso terus meningkat. Pada tahun 2013 jumlah outlet di Bondowoso adalah sebanyak 422 unit, tahun 2014 sebanyak 476 dan tahun 2015 sebanyak 509 unit. Jumlah ini terus meningkat pada tahun 2016 yaitu sebanyak 568 dan tahun 2017 sebanyak 628 unit. Angka ini mengindikasikan bahwa semakin banyak masyarakat yang mempercayai Telkomsel sebagai operator seluler terbaik, dan juga mempercayai PT. Graha Central Indo sebagai perusahaan penyedia telkomsel.

Berikut ini adalah hasil penelitian terdahulu seperti hasil penelitian Mediasiwaskito Budi Susetyo yang menghasilkan kesimpulan bahwa variabel kualitas pelayanan mempengaruhi loyalitas pelanggan (Susetyo, 2010). Selain itu Pongoh menjelaskan bahwa variabel harga ternyata berpengaruh positif terhadap Loyalitas pelanggan (Pongoh, 2013). Lebih lanjut Pratiwi dalam penelitiannya menghasilkan kesimpulan bahwa variabel kepuasan konsumen berpengaruh positif dan signifikan terhadap loyalitas(Pratiwi, 2010). Berangkat dari uraian tersebut guna mengetahui kinerja PT. Graha Central Indo Bondowoso dari aspek layanan, harga serta produk, diperlukan penelitian lebih lanjut lagi mengenai pengaruh kualitas pelayanan, harga dan produk terhadap kepuasan pelanggan.

Tujuan dari penelitian ini adalah untuk menguji dan menganalisa pengaruh kualitas pelayanan, produk dan harga terhadap kepuasan pelanggan Telkomsel Flash di Kabupaten Bondowoso

\section{Metode}

Desain penelitian ini adalah penelitian kausalitas. Penelitian kausalitas bertujuan mengukur kekuatan hubungan antara dua variabel atau lebih, juga menunjukkan arah hubungan antara variabel bebas dan terikat. Secara umum tujuan penelitian ini untuk melihat, membuktikan dan menganalisis apakah kualitas pelayanan, harga dan produk terhadap kepuasan pelanggan. Populasi dalam penelitian ini adalah seluruh pengguna Telkomsel Flash di Bondowoso, yaitu sebanyak 156.000 orang. Sedangkan untuk menghitung penentuan jumlah sampel dari populasi tertentu, penelitian ini menggunakan rumus Slovin dan diperoleh angka 100 responden

\section{Hasil dan pembahasan}

\section{Uji Instrumen Data}

Uji Validitas

Uji validitas dilakukan untuk mengetahui kehandalan kuesioner. Item pernyataan dianggap valid apabila nilai $r$ hitung lebih besar dibandingkan $r$ tabel.

Tabel 3. Hasil Uji Validitas

\begin{tabular}{llccl}
\hline No & Item Pernyataan & r tabel & r hitung & Ket \\
\hline 1. & Kualitas Pel. 1 & 0,1966 & 0,532 & Valid \\
& Kualitas Pel. 2 & & 0,498 & \\
& Kualitas Pel. 3 & & 0,543 & \\
& Kualitas Pel. 4 & 0,520 & \\
& Kualitas Pel. 5 & 0,606 & \\
\hline
\end{tabular}




\begin{tabular}{|c|c|c|c|}
\hline \multirow[t]{4}{*}{2.} & Harga 1 & 0,542 & Valid \\
\hline & Harga 2 & 0,532 & \\
\hline & Harga 3 & 0,465 & \\
\hline & Harga 4 & 0,233 & \\
\hline \multirow[t]{8}{*}{3.} & Produk 1 & 0,394 & Valid \\
\hline & Produk 2 & 0,481 & \\
\hline & Produk 3 & 0,492 & \\
\hline & Produk 4 & 0,378 & \\
\hline & Produk 5 & 0,439 & \\
\hline & Produk 6 & 0,413 & \\
\hline & Produk 7 & 0,338 & \\
\hline & Produk 8 & 0,424 & \\
\hline \multirow[t]{5}{*}{4.} & Kep.Pelanggan 1 & 0,677 & Valid \\
\hline & Kep.Pelanggan 2 & 0,615 & \\
\hline & Kep.Pelanggan 3 & 0,552 & \\
\hline & Kep.Pelanggan 4 & 0,669 & \\
\hline & Kep.Pelanggan 5 & 0,629 & \\
\hline
\end{tabular}

Dari data di atas diketahui bahwa semua item pernyataan dalam kuesioner memiliki nilai $r$ hitung lebih besar dari $r$ tabel yaitu sebesar 0,1966, artinya semua item yang digunakan dalam penelitian ini dapat dikatakan valid.

Uji Reliabilitas

Uji reliabilias kuesioner dilakukan dengan tujuan untuk mengetahui konsistensi dan stabilitas dari alat ukur. Hasil uji reliabilitas disajikan pada tabel di bawah ini:

Tabel 4. Hasil Uji Reliabilitas

\begin{tabular}{l|l|l|l}
\hline No. & Variabel & Cronbach Alpha & Ket \\
\hline 1. & Kualitas Layanan & 0,767 & Reliabel \\
2. & Harga & 0,706 & Reliabel \\
3. & Produk & 0,691 & Reliabel \\
4. & Kepuasan Pelangan & 0,748 & Reliabel \\
\hline
\end{tabular}

Dari nilai di atas diketahui masing-masing item memiliki nilai yang lebih besar dari 0,6, artinya semua item yang digunakan dalam penelitian ini adalah reliabel.

\section{Uji Asumsi Klasik}

Uji Normalitas

Tabel 5. Hasil Uji Normalitas

\begin{tabular}{llll}
\hline No. & Variabel & Nilai Z Kolm.Smirnov & Sig \\
\hline 1. & Kualitas Layanan & 1,249 & 0,088 \\
\hline 2. & Harga & 1,193 & 0,116 \\
\hline 3. & Produk & 1,077 & 0,196 \\
\hline
\end{tabular}

Hasil di atas menunjukkan bahwa nilai signifikansi masing-masing variabel adalah lebih besar dari $\alpha$ $(0,05)$, sehingga data dari variabel penelitian dapat dikatakan berdistribusi normal.

Uji Multikolinearitas

Tabel 6. Hasil Uji Multikolinearitas

\begin{tabular}{llll}
\hline No. & Variabel & Tolerance & VIF \\
\hline 1. & Kualitas Layanan & 0,676 & 1,479 \\
2. & Harga & 0,695 & 1,438 \\
3. & Produk & 0,618 & 1,618 \\
\hline
\end{tabular}


Hasil di atas menunjukkan bahwa masing-masing variabel memiliki nilai VIF kurang dari 10, sehingga dapat disimpulkan variabel independen tidak terjadi multikolinearitas.

Uji Heteroskedastisitas

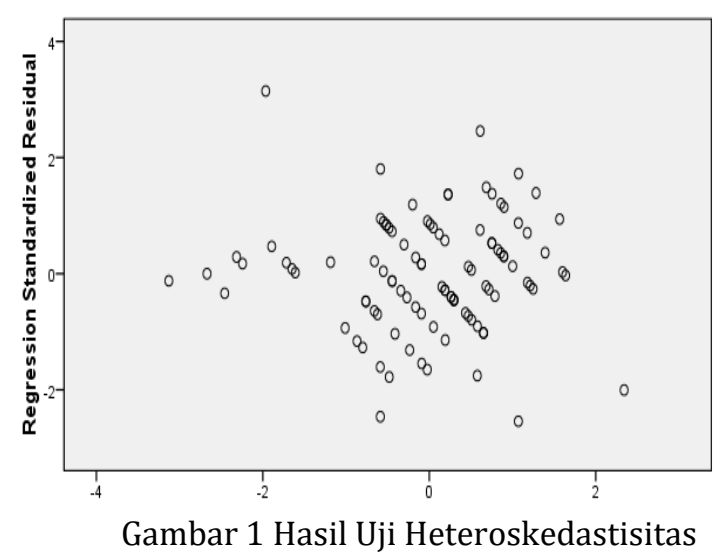

Dari gambar grafik 4.1 di atas, dapat dilihat bahwa pola tidak terlihat jelas dan titik-titik menyebar di atas dan di bawah adalah angka nol pada sumbu, sehingga variabel penelitian dapat disimpulkan tidak ada heteroskedastisitas.

\section{Regresi Linier Berganda}

Analisis linier berganda digunakan untuk memperoleh gambaran menyeluruh mengenai hubungan antara variabel satu dengan variabel lainnya.

Tabel 7. Hasil Uji Regresi Linier Berganda

\begin{tabular}{llll}
\hline \multirow{2}{*}{ Model } & \multicolumn{2}{l}{ Unstandardized Coefficients } & Standardized Coefficients \\
\cline { 2 - 4 } & $\mathrm{B}$ & Std. Error & Beta \\
\hline (Constant) & .596 & 1.293 & \\
Kualitas Layanan & .264 & .060 & .289 \\
Harga & .196 & .068 & .186 \\
Produk & .395 & .050 & .538 \\
\hline
\end{tabular}

Hasil perhitungan analisis regresi linier berganda diperoleh persamaan: $\mathrm{Y}=0,596+0,264 \mathrm{X} 1+0,196 \mathrm{X} 2+0,395 \mathrm{X} 3$

Dari persamaan regresi di atas dapat dilihat nilai konstanta sebesar 0,596, yang artinya bahwa jika variabel independen yang meliputi kualitas pelayanan, ketersediaan fasilitas, dan kemudahan birokrasi dianggap konstan maka besarnya nilai adalah sebesar 0,596. Koefisien regresi variabel kualitas pelayanan bernilai positif sebesar 0,264 , yang berarti bahwa peningkatan kualitas layanan sebesar satu satuan akan terjadi peningkatan kepuasan mahasiswa sebesar 0,264 dengan asumsi variabel bebas lainnya konstan. Begitupula dengan nilai variabel harga dan produk yang bernilai positif sebesar 0,196 dan 0,395 pada masing-masing variabel.

Uji t

Uji t digunakan untuk mengetahui pengaruh variabel independen terhadap variabel dependen secara parsial. Berikut hasil uji t dalam penelitian ini:

Tabel 8. Hasil Uji t

\begin{tabular}{lllll}
\hline No & Variabel & t-hitung & t-tabel & Sig. \\
\hline 1. & Kualitas Layanan & 4,418 & 1,66159 & 0,000 \\
2. & Harga & 2,884 & & 0,005 \\
3. & Produk & 7,875 & & 0,000 \\
\hline
\end{tabular}


Nilai t-hitung variabel Kualitas layanan adalah sebesar 4,418 dengan tingkat signifikansi sebesar 0,000, sedangkan nilai t-tabel adalah sebesar 1,66159 sehingga t-hitung > t-tabel dan signifikansi lebih kecil dari 0,05. Hal ini menunjukkan bahwa variabel kualitas layanan secara parsial mempunyai pengaruh positif dan signifikan terhadap kepuasan pelanggan.

Nilai t-hitung variabel Harga adalah sebesar 2,884 dengan tingkat signifikansi sebesar 0,005, sedangkan nilai t-tabel adalah sebesar 1,66259, sehingga t-hitung $>$ t-tabel dan signifikansi lebih kecil dari 0,05 . Hal ini menunjukkan bahwa variabel harga secara parsial mempunyai pengaruh positif dan signifikan terhadap kepuasan pelanggan.

Nilai t-hitung variabel Produk adalah sebesar 7,875 dengan tingkat signifikansi sebesar 0,000, sedangkan nilai t-tabel adalah sebesar 1,66159, sehingga t-hitung $>$ t-tabel dan signifikansi lebih kecil dari 0,05 . Hal ini menunjukkan bahwa variabel produk secara parsial mempunyai pengaruh positif dan signifikan terhadap kepuasan pelanggan.

\section{Koefisien Determinasi}

Koefisien Determinasi $\left(\mathrm{R}^{2}\right)$ digunakan untuk mengetahui seberapa besar kemampuan variabel independen dapat menerangkan variabel dependennya. Hasil perhitungan $\mathrm{R}^{2}$ dapat dilihat dalam tabel di bawah ini:

Tabel 9. Hasil Uji Koefisien Determinasi

\begin{tabular}{llll}
\hline Model & $\mathrm{R}$ & R Square & Adjusted R Square \\
\hline 1. & $0,850^{\mathrm{a}}$ & 0,723 & 0,715 \\
\hline
\end{tabular}

Berdasarkan data di atas, diketahui bahwa nilai $\mathrm{R}^{2}$ sebesar 0,715 , yang artinya bahwa kualitas layanan, harga dan produk berpengaruh $71,5 \%$ terhadap kepuasan mahasiswa, sedangkan sisanya sebesar $28,5 \%$ dipengaruhi oleh faktor lain di luar model.

\section{Pembahasan}

Pembahasan untuk masing-masing variabel adalah sebagai berikut:

1. Pengaruh kualitas layanan terhadap kepuasan pelanggan

Kualitas layanan merupakan upaya perusahaan dalam memenuhi kebutuhan dan keinginan pelanggan serta ketepatan penyampaiannya dalam mengimbangi harapan pelanggan (Tjiptono, 2007). Kualitas layanan yang baik, handal, tepat waktu, dan cepat dalam penanganan keluhan merupakan nilai penting dimata pelanggan PT. Graha Central Indo Bondowoso. Perusahaan yang mampu memberikan layanan yang berkualitas dan maksimal akan menciptakan kepuasan bagi pelanggan.

Hal tersebut sesuai dengan hasil pengujian pada penelitian ini yang membuktikan bahwa variabel kualitas layanan secara parsial berpengaruh positif dan signifikan terhadap kepuasan pelanggan PT. Graha Central Indo Bondowoso. Berdasarkan hasil ini maka hipotesis yang menyatakan kualitas layanan berpengaruh positif terhadap kepuasan pelanggan dapat diterima. Hasil temuan ini sejalan dengan hasil penelitian yang dilakukan oleh Sari dkk (2016), Santoso(2016) yang mendapatkan hasil bahwa kualitas layanan berpengaruh positif dan signifikan terhadap kepuasan pelanggan.

2. Pengaruh Harga terhadap Kepuasan Pelanggan

Faktor kedua yang mempengaruhi kepuasan pelanggan adalah harga. Harga adalah sejumlah uang yang harus dibayar oleh pelanggan untuk memperoleh produk (Kotler dan Armstong, 2007). Penetapan harga merupakan kebijakan perusahaan, namun tetap perlu mempertimbangkan faktor pelanggan dalam penetapannya. Jika harga yang ditetapkan sesuai dengan manfaat dan kualitas, maka nilai dari harga dapat dikatakan meningkat. Apabila nilai dari suatu harga yang dirasakan pelanggan meningkat, maka kepuasan pelanggan akan tercipta.

Hal tersebut sesuai dengan hasil penelitian ini yang membuktikan bahwa variabel harga secara parsial berpengaruh positif dan signifikan terhadap kepuasan pelanggan PT. Graha Central Indo Bondowoso. Berdasarkan hasil ini maka hipotesis yang menyatakan harga berpengaruh positif terhadap kepuasan pelanggan dapat diterima. Hasil temuan ini sejalan dengan hasil penelitian yang dilakukan oleh Sari dkk (2016), Suwarni dkk (2011) dan Utami dkk (2016), Santoso(2016) yang mendapatkan hasil bahwa harga berpengaruh positif dan signifikan terhadap kepuasan pelanggan.

3. Pengaruh Produk terhadap Kepuasan Pelanggan

Hasil pengujian membuktikan bahwa variabel produk secara parsial berpengaruh positif dan signifikan terhadap kepuasan pelanggan PT. Graha Central Indo Bondowoso. Berdasarkan hasil ini maka hipotesis yang menyatakan produk berpengaruh positif terhadap kepuasan pelanggan dapat diterima. Hasil temuan ini sejalan dengan hasil penelitian yang dilakukan oleh Sari dkk (2016), Suwarni dkk (2011) 
dan Utami dkk (2016), Santoso (2016) yang mendapatkan hasil bahwa harga berpengaruh positif dan signifikan terhadap kepuasan pelanggan. Selain itu penelitian oleh Nalendra (2018) menunjukkan adanya pengaruh positif antara kualitas pelayanan terhadap loyalitas konsumen pelanggan

Produk didefinisikan sebagai segala sesuatu yang ditawarkan ke pasar untuk memuaskan keinginan dan kebutuhan (Kotler, 2002). Menurut Kotler dan Armstong (2012) kualitas produk merupakan karakteristik dari sebuah produk atau jasa yang memiliki kemampuan untuk memuaskan atau memenuhi kebutuhan pelanggan. Produk yang berkualitas akan memenuhi harapan dan keinginan pelanggan, sehingga mampu menciptakan kepuasan pelanggan PT. Graha Central Indo Bondowoso

\section{Simpulan dan saran}

Berdasarkan analisis data dan pembahasan yang telah dikemukakan, maka hasil penelitian ini dapat disimpulkan: 1. Kualitas layanan berpengaruh positif dan signifikan terhadap kepuasan pelanggan PT. Graha Cental Indo Bondowoso, 2. Harga berpengaruh positif dan signifikan terhadap kepuasan pelanggan PT. Graha Cental Indo Bondowoso, 3. Produk berpengaruh positif dan signifikan terhadap kepuasan pelanggan PT. Graha Cental Indo Bondowoso,

Saran yang dapat penulis ajukan sehubungan dengan hasil penelitian ini yaitu: 1. Untuk Instansi: hasil penelitian menunjukkan bahwa kualitas layanan, harga dan produk berpengaruh positif dan signifikan terhadap kepuasan pelanggan, sehingga perusahaan diharapkan mampu mempertahankan dan meningkatkan faktor-faktor tersebut untuk menciptakan kepuasan pelanggan, 2. Untuk peneliti berikutnya: peneliti berikutnya diharapkan menetapkan jumlah sampel yang lebih luas menggunakan rumus Slovin dengan tingkat 0,05 , agar diperoleh jumlah sampel yang lebih banyak sehingga hasil penelitian dapat digeneralisasikan lebih luas.

\section{Daftar Rujukan}

Assauri, Sofyan. 2008. Manajemen Pemasaran, Dasar Konsep Dan Strategi. Raja Grafindo: Jakarta

Bachmid, Abdurrahman Fauzi Et Al. 2016. Analisis Kualitas Produk, Promosi, Dan Harga Terhadap Keputusan Pembelian Kartu Telkomsel 4G LTE Di Manado (Studi Kasus: Fakultas Ekonomi Dan Bisnis Di Universitas Sam Ratulangi). Jurnal EMBA Vol.4 No.4. Universitas Sam Ratulangi: Manado

Hutapea, Roni Afrianto. 2016. Pengaruh Kualitas Produk Dan Harga Terhadap Kepuasan Pelanggan Kartu Prabayar Telkomsel Pada Mahasiswa Fakultas Ekonomi Universitas Asahan. Tesis. Universitas Terbuka: Jakarta

Kotler, Philip. 2002. Manajemen Pemasaran. Prenhalindo: Jakarta

Kotler, Philip Dan Armstong, Gary. 2007. Dasar-Dasar Pemasaran. Indeks: Jakarta

Kotler, Philip Dan Armstong, Gary. 2012. Principles of marketing. Person education limited: new jersey

Kotler, Philip Dan Keller, Kevin Lane. 2009. Manajemen Pemasaran, Edisi Ketigabelas, Alih Bahasa: Benyamin Molan. Indeks: Jakarta.

Maulana, Ade Syarif. 2016. Pengaruh Kualitas Pelayanan Dan Harga Terhadap Kepuasan Pelanggan Pt. Toi. Jurnal Ekonomi Volume 7 Nomor 2.

Nalendra, Aloysius Rangga Aditya. 2018. Pengaruh Kualitas Pelayanan Harga Kepuasan Pelanggan Terhadap Loyalitas Pelanggan (Studi Kasus Pelanggan Im3 Madiun). Jurnal Ilmu Pengetahuan Dan Teknologi Komputer Volume 3 No 2.

Nugroho, Novemy Triyandari. 2014. Pengaruh Kualitas Pelayanan Terhadap Kepuasan Dan Loyalitas Pelanggan (Survey Pada Pelanggan Speedy Telkom Di Kota Surakarta. Jurnal Paradigma Vol.12 No.02. STMIK Duta Bangsa: Surakarta

Pongoh, M. (2013). Kualitas pelayanan, Kualitas Produk Dan Harga Pengaruhnya Terhadap Loyalitas Pelanggan Kartu As Telkomsel Di Kota Manado. Jurnal EMBA Universitas Sam Ratu Langi Manado, Vol.1 No.4, 86-94.

Pratiwi, I. D. (2010). Analisis Pengaruh Harapan Pelanggan, Kualitas Produk, Kepuasan Pelanggan Terhadap Loyalitas Pelanggan Internet Flash Unlimited Di Semaran. Skripsi tidak diterbitkan Semarang:Universitas Diponogero Semarang. 
Sari, Dessica Dinar Dan Utama, Agung. 2016. Analisis Pengaruh Kualitas Produk, Kualitas Pelayanan Dan Harga Terhadap Kepuasan Konsumen (Studi Kasus Pada Konsumen Sim Card Gsm Prabayar XL Di Kota Yogyakarta. Jurnal. Universitas Negeri Yogyakarta: Yogyakarta

Santoso, B, 2016, Pengaruh Dimensi Kualitas Layanan terhadap kepuasan Pelanggan Hotel Tanjung Asri Banyuwangi, Jurnal Ilmu manajemen dan Bisnis Vol 2 No,2 UM Jember

Suriyani. 2017. Pengaruh Bauran Pemasaran Terhadap Kepuasan Konsumen Pengguna Layanan 4G Telkomsel Di Samarinda Seberang. Ejournal Adiminstrasi Bisnis Vol.5 No.2. Universitas Mulawarman: Samarinda

Susetyo, M. (2010). Pengaruh Kualitas Layanan PT Indosat Terhadap Loyalitas Pelanggan IM3 di wilayah Kabupaten Wonogiri Dengan Kepuasaan Sebagai Variabel Mediasi. Universitas Sebelas Maret Surakarta.

Suwarni Dan Mayasari, Septina Dwi. 2011. Pengaruh Kualitas Produk Dan Harga Terhadap Loyalitas Melalui Kepuasan Konsumen. Jurnal Ekonomi Bisnis Th.16 No.1. Universitas Negeri Malang: Malang

Tjiptono, Fandy. 2006. Prinsip-Prinsip Total Quality Service. Bayumedia Publishing: Malang

Utami, Athira Tjahya Dan Trenggana, Arlin Ferlina Moch. 2016. Pengaruh Kualitas Produk Dan Harga Terhadap Kepuasan Konsumen Pengguna Telkomsel (Studi Pada Mahasiswa Universitas Telkom Bandung. E-Proceeding Of Management Vol.3 No.1. Universitas Telkom: Bandung

Zeithaml dan Bitner. 2003. Service Marketing Integrating Customer Focus Across the Firm. Mc GrowHill/Irwin: Boston 